\title{
VLADISLAV GALIMSKIY IN THE CONTEXT OF KYIV ASSOCIATION OF ART EXHIBITIONS (1893-1900)
}

\author{
Ihor Ponamarchuk \\ Postgraduate Student at the Department of Art History, \\ Taras Shevchenko National University of Kyiv, Ukraine \\ e-mail: goldtyt@gmail.com, orcid.org/0000-0001-6027-4159
}

\section{Summary}

The article analyses the life and creative journey of the artist of Polish origin Vladyslav Galimskiy (1860 - 1940), who lived and worked in Kyiv. The main milestones of the artist's life are elucidated. The author specifies his involvement in the exhibition life of Kyiv. Particular attention is paid to the story behind Kyiv Association of Art Exhibitions and the role played by V. Galimskiy and other local artists. The history of holding five exhibitions by Kyiv Association of Art Exhibitions is described in detail, and the reasons for the Association's decline are examined. The creative journey of the artist after the Association's shutdown is considered. The research covers Galimskiy's participation in charitable activities through the prism of his engagement in the organization of "living paintings" (small amateur performances) in favor of a free hospital and fundraising for a new Roman Catholic Church in Kyiv. A very valuable appendix is attached to the article: it is a complete novel list based on the art catalogs comprising more than 70 paintings by Galymsky presented at Kyiv exhibitions in the 1890s.

Keywords: Vladyslav Galimskiy, Kyiv Association of Art Exhibitions, exhibition catalog, artistic life of Kyiv, living paintings.

\section{DOI: https://doi.org/10.23856/4708}

\section{Introduction}

Vladyslav Mykhailovych Galimskiy (1860-1940), the artist of Polish origin, was a very prominent figure in the artistic life of Kyiv of the late 19th and early 20th centuries. He was the organizer and exhibitor at the Exchange Hall, one of the founders of Kyiv Association of Art Exhibitions, a member of Kyiv Association for Arts Promotion, and Kyiv Society of Antiquities and Arts. However, the artist's activities and his considerable creative legacy have been poorly studied.

\section{The first art exhibitions of V. Galimskiy}

The future artist was born into a noble family in 1860 in Kyiv. He studied at the Second Kyiv Gymnasium (1871-1873) and Kyiv Real School (1873-1877) (DAK, spr.55: 1,5) and then, in the Imperial Academy of Arts where, on October 31, 1888, he was awarded the title of class artist of landscape painting of the first degree (Kondakov, 2002: 56). In the same year, the artist came back to Kyiv and embarked upon his professional activity (Kartiny hudozhnika, 1913: 148-149; Yubilej hudozhnika, 1913: 4; Yubilej V. M. Galimskogo, 1913: 7; Fotoportret, 1914: 9).

Before long, Vladyslav Galimskiy became a participant in exhibitions of local artists, which were held annually in the Exchange Hall. His paintings, predominantly landscapes, were presented in February-March 1889 (W, 1889: 203-205), January-February 1890 (apparently, the 
artist also had organizational skills because he made the top five initiators of the event (DAKO, spr. 53: 1-2)), January-March 1891 (DAKO, spr. 53: 8; Ertel, 1891, no 25: 3; Igolka, 1891: 2-3; Igolka (Okonchanie), 1891: 2), December 1891 - January 1892 (TsDIAK, spr. 26: 1-2; DAKO, spr. 53: 32-36, Ertel, 1891, no 285: 2; Z, 1892: 331-333), and in December 1892 - January, 1893 ( TsDIAK, spr. 233: 7; DAKO, spr. 53: 14-17 vol.). V. Galimskiy concurrently participated in the exhibitions of Kiyv Association for Arts Promotion - he was its full member since its foundation in 1890 (DAKO, spr. 53: 60-62 vol., 64). In particular, his works were presented at the exhibition of studies and sketches in 1892, as well as at the exhibition of paintings by Russian and foreign artists in 1896 (he was engaged in its organization as one of the members of the exhibition committee).

\section{Foundation of Kyiv Association of Art Exhibitions}

On October 24, 1892, Mykola Murashko, Mykola Pymonenko, and Vladyslav Galimskiy appealed to the governor of Kyiv to assist them in establishing the local Association of Art Exhibitions, the first professional society of Kyiv artists. In addition to the three commissioners, the petitions were signed by Ivan Seleznyov, Count Alexander de Balmen, Pavlo Kovalevsky, Khariton Platonov, Wilhelm Kotarbiński, Mykola Bodarevsky, Volodymyr Menk, Ivan Rashevsky, Yosyp Budkevych, Pavlo and Oleksandr Svedomsky, Yevhen Wrzeszcz, Ivan Stanivsky, and Ivan Tereshchenko (TsDIAK, spr. 183: 14; DAKO, spr. 261: 1-1 vol.). However, soon a conflict arose between the older and younger generations of artists, who were to form the core of the future Association, in which V. Galimskiy played a part. The only source that can shed light on this situation is the article by Kyiv archaeologist and critic Alexander Ertel, who wrote the following: As for "the youth", they behaved with a tact worthy of praise: first of all, none of the young people wanted to be named founders of the association, giving way to the elders, and their only wish was that upon approval of the charter, 4 of the young: Messrs. Kozlovsky, Danilov, Sevastyanov and Kostenko, who annually presented their art works, eo ipso would be considered members of the association without being subject to specific election mandatory for all others. The offer was supported by I. F. Seleznyov, and Professor Orlovsky also made a condition to add the writer of these lines and Mr. L. A. Gaidukov to the above 4. Moreover, he did not agree to sign the charter until satisfying the above requirements. How did that turn out? The charter was signed and sent for approval without the knowledge of all participants; the promise to add 4 named persons and 2 additional was not fulfilled (prof. Orlovsky didn't sign the charter). In 1892-93, when the charter was returned for stamp duty payment and providing information about some signatories, i.e., when any association was out of the question, $M r$. Galimskiy as a "secretary" of the association, although it did not yet exist, initiated active and, at the same time, too official preparations for the exhibition" (Ertel, 1893, no 1875: 1). Only heaven knows what the last words underlined by the very author meant. However, in December of 1892, it was Galimskiy who petitioned Kyiv authorities, not as a secretary but as a private person, to open another exhibition in the Exchange Hall (TsDIAK, spr. 233: 7; DAKO, spr. 53: 14-17 vol.). And then, according to the critic, "Having learned that the 4 mentioned persons were ignored and new association means no good, Mr. Seleznyov has refused to join it; young people, about 30 persons, also decided not to present their paintings at the exhibition of the hotly disputed association and think about how to do away with unnecessary and hampering any development care of unrecognized leaders represented by Messrs. Murashka, Galimskiy, Kotarbiński et al. once and forever (Ertel, 1893, no 1875: 1). At the end of February 1893, the conflict was triggered by the fact that I. Seleznyov managed to organize another exhibition of 
“the youth" (TsDIAK, spr. 43: 4-5; DAKO, spr. 53: 6-11 vol.) or "spring men” (vesnianyky), as they were called proceeding from the time chosen to hold their events. Looking ahead, it should be noted that "youth" ran their exhibitions for three years in a row (TsDIAK, spr. 51: 10-11; DAKO, spr. 53: 34-39 vol.; TsDIAK, spr. 58: 4-4 vol.; DAKO, spr. 53: 7-12 vol.) after which their activities in that format ceased. The exhibitions of "spring men" were not marked by bright talents - the historian O. Kovalenko writes - but all their participants were supporters of the realistic school of painting. It is not surprising, because of 32 artists who took part in the first exhibition of "spring men", 22 were alumni of M. I. Murashko school ..." (Kovalenko, 1972: 83). Unfortunately, we are aware of the misunderstanding between the two generations of Kyiv artists based on the information provided by O. Ertel (however, he could hardly be objective because he belonged to "spring men").

As for I. Seleznyov, he did not take part in any of the events of the newly formed Kyiv Association of Art Exhibitions (KAAE) but took care of organizing spring events (signing, by the way, a request as a KAAE commissioner) and providing them with his works.

The role of Volodymyr Orlovsky in the organization of the Association remains somewhat unclear. On the one hand, in a letter to Pyotr Nilus, Eugene Wrzeszcz mentions his name among the founders of the association (Fedoruk, 2009, Yevhen Vzheshch: 374-375), and on the other hand, Orlovsky did not sign a petition to the authorities in autumn 1892, as I. Seleznyov had done before the conflict. However, his works appeared at one of the KAAE exhibitions.

O. Ertel's bias towards "unrecognized leaders" is traced in his negative review of the December exhibition in 1892 (Ertel, 1893, no 1796: 2-3), compared to the review of the April event of "spring men" in which he participated. With the knowledge that such a publication may cause outrage among Kyiv artists, the editorial staff of the newspaper "Kievskoe Slovo" reserved the right to act and assess at their discretion, which was manifested in a more friendly review (P.N., 1893: 2-3; P.N. (Okonchanie), 1893:2).

During the approval of the KAAE charter, there were serious changes in the professional life of V. Galimskiy. First, he became a participant of the World's Columbian Exposition in Chicago (Official Catalog, 1893), and the newspaper "Russkoe Slovo" announced that the jury awarded the artist a gold medal (Yubilej V. M. Galimskogo, 1913:7). Second, in the same 1893, he obtained the title of academician (Kondakov, 2002: 56) that gave him an undeniable advantage over colleagues.

The KAAE charter approved on September 28, 1893, stated: "The association aims to arrange a paid exhibition of artworks with the relevant permission: to sell both artworks and catalogs and pictures of art works"; (Ustav, 1893). It was the point that provoked sharp criticism by art critic Yevhen Kuzmin: "In fact, sale is the only goal that created, inspired, and united Kyiv "Association" at the rare meetings of its members (once or twice a year). At least, nothing else was said in the charter, and nothing else was implemented" (Kuzmin, 1900: 317).

Since the establishment of KAAE, it had been headed by Professor Pavlo Kovalevskyi, while the secretaries changed every year. At the beginning of 1894, these responsibilities were assigned to E. Wrzeszcz, but as he wrote "given ill health and the fact that I live in the countryside, I have refused to manage the affairs of our association. I have much of a hassle and trouble" (Fedoruk, 2009, Pejzazhnij zhivopis: 528). In due course, I. Stanislavsky became the secretary, a year later - I. Rashevsky, in 1896 - V. Menk. As for V. Galimskiy, he held the position of treasurer for some time (NAFRF IMFE, spr. 95: 16-16 zv.). 


\section{KAAE exhibition activity}

The first exhibition of Kyiv Association of Art Exhibitions opened on January 26, 1894, at the University of St. Vladimir (TsDIAK, spr. 51:1-2; DAKO, spr. 53: 20-24; Pervaya vystavka, 1894: 2; Dilletant, 1894: 1-2; Ertel, 1894: 2) where, at that time, members of the famous Wanderers planned to present their artworks. Yegor Khruslov, the Commissioner for Exhibitions of Wanderers, describes in a letter to Mykola Yaroshenko why this happened in detail and emotionally, though not quite reliably: "Local artists started bustling about the hall at the University long before its building renovation. There was the involvement of people with influence and even deception that one of the artists said they had got in touch with me and I had announced that our exhibition would commence when they closed theirs. Therefore, you can judge how it is difficult to foresee all the meanness some are capable of. Without expecting to hold the hall of the University, the local artists concurrently asked the homeowner N. G. Hryakov for a facility. When I arrived, two of the artists, Wrzeszcz and Galimskiy, pointed me to this house. <...>

I talked to Hryakov because local artists occupied the room we usually did. They pointed me to an apartment in his house, which they weren 't interested in ostensibly they would exhibit a huge painting by Kotarbiński, as it didn't fit in the apartment. Hryakov provided the facility" (Tovarishestvo, 1987: 443).

E. Khruslov claims that Kyiv artists had started bustling about the university hall long before building renovation was completed, although the appeal of KAAE commissioners to Kyiv governor is dated January 20, 1894 (DAKO, spr. 53:21), i.e., less than a week before the scheduled opening. By the way, the mentioned huge painting by Kotarbiński was "Messalina" $(300 \times 500 \mathrm{~cm})$. For some unknown reasons, it was not listed in the catalog and appeared in the exhibition after February 5 that was individually reported by Kyiv newspapers (Kievlyanin, 1894: 3; Zhizn $i$ iskusstvo, 1894: 1; Kievskoe slovo, 1894, №2185: 1; № 2187: 1; № 2189: 1). Nowadays, this art piece is stored in Kyiv Museum "Spiritual Treasures of Ukraine".

In addition to the mentioned E. Wrzeszcz and V. Galimskiy, Kyiv representatives M. Murashko, V. Menk, M. Pymonenko, H. Platonov, S. Svitoslavsky, Odessans P. Gansky, O. Stilianudi, B. Edwards, and many other painters took part in the exhibition.

It is interesting that during seven years of the Association's existence, none of the artworks submitted to the exhibition was considered by Kyiv police chief to be such that they could not be presented to the public "according to the tendencies of their content".

The author also specifies that KAAE held only the first two exhibitions in the university hall and then returned to the Exchange Hall (as it was before the official association of artists). The latter was exhibited at the museum of Kyiv Society of Antiquities and Arts (now National Art Museum of Ukraine). The reason for such migration was the search for the most convenient place for the public: "The trouble is that only one university provides a hall for exhibitions. Although the hall is nice and huge, there is one inconvenience: the university is far from the city center, and our whole life is concentrated only on Khreshchatyk. Our exhibitions on Khreshchatyk were two or three times better than at the university; I finally have come to this conclusion..." Fedoruk, 2009, Yevhen Vzheshch: 350) - E. Wrzeszcz wrote in a letter to P. Nilus. However, the very exhibitions could be a reason, as the wanderers succeeded in their events at the University, and the "distance" from the center did not frighten them at all.

In early December 1894, I. Stanislavsky, the then secretary of KAAE, invited Odesa artists to join Kyiv ones at the next second exhibition (NAFRF IMFE, spr. 93: 19-20), which was to open on December 26 (TsDIAK, spr. 51: 14-14 zv; DAKO, spr. 53: 66-70). The invitation sent to Odesa is one of the few sealed documents written on the official letterhead of KAAE. It 
has a special value, because we know very little about the activities of KAAE. However, Odesa artists did not present their artworks in Kyiv that year - it is likely because they planned to open their exhibition in spring.

In the middle 1890s, the artistic life of Kyiv noticeably revived, but the organization of exhibitions required appropriate premises, and this was challenging. "Unfortunately, in Kyiv, we now have only one hall for exhibitions - at the university, given that this year a lot of exhibitions have appeared in the city. There must be an opinion about Kyiv as a city really good for exhibitions, but, in reality, this opinion is quite unsound" - E. Wrzeszcz wrote in one of the letters and then added: "Imagine, there have already been three exhibitions in Kiev this year: of Lagorio, the St. Petersburg Society, and Kiev Association for Art Promotion. Ours will be the fourth, mobile - the fifth, your-sixth, other group of spring men - the seventh" (Fedoruk, 2009, Pejzazhnij zhivopis: 528).

The third exhibition of KAAE (TsDIAK, spr. 58: 8-8 зв; DAKO, spr. 53: 21-25) became a striking example of the cooperation of Kyiv artists with Odesa ones: M. Aleksomati, E. Bukovetsky, P. Gansky, V. Zauze, K. Kostandi, P. Nilus, and others. A retrospective of J. Budkevych, who died in early December 1895, was also held as part of the event (Skitalec, 1896: 2-3).

At the IV exhibition of KAAE (TsDIAK, spr. 60: 3-4; DAKO, spr. 53: $73-78 \mathrm{zv}$ ), which lasted from December 29, 1896, to February 9, 1897, V. Galimskiy presented six completed paintings and 12 studies, which, unfortunately, did come to the attention of critics. Instead, at the V exhibition, his artwork "Moonlight night" attracted public attention. Even 20 years later, when the artist re-exhibited this landscape, the critic Hryhorii Shvarts described it as one of the most interesting paintings (IR NBUB, od. zb. 2:4).

The last exhibition of KAAE opened in City Museum and lasted from January 1 to February 6, 1900 (Don Bazilio, 1900, №4310: 3; № 4313: 2; № 4315: 2). It was attended by almost 4,000 art lovers, and the collection of entrance tickets amounted to about 1,000 rubles (Kiev, 1900: 228) (an adult ticket cost 35 kopecks, a ticket for children, pupils, students 20 kopecks.) (Kievlyanin, 1900:1). As the statistics of attendance of Kyiv exhibitions were recorded unsystematically at that time and newspapers seldom provided such information, the figures are difficult to compare. The Wanderers were most likely the only organization that collected relevant data from year to year. Thus, in 1898, their exhibition was visited by more than 6,000 people (Tovarishestvo, 1987: 532-533) that undoubtedly surpassed the KAAE rate. However, the lag is not very significant, and it clearly demonstrates the interest of the local public in the creative activities of Kyiv artists.

Determining the reasons for the Association's decline, researchers often stress that at some point, its members completely switched to the organization of a permanent exhibition, Art Salon (Severyuhin et al., 1992: 87). However, O. Kovalenko emphasized the more important: "Kyiv Association of Art Exhibitions did not defend any specific ideas of the development of national art but strove to unite artists living in the city, regardless of their creative interests, into a single organization to revive the artistic life of Kyiv. The artworks of both representatives of the realistic school of painting and the late academic salon art attracted the equal attention of the audience and art critics. (Kovalenko, 1972: 84). Although the unification played an essential role in the artistic life of Kyiv, its contribution is difficult to compare with the contribution of the Society of South Russian Artists in Odesa. 


\section{Oeuvre of the artist after closing KAAE}

After the shutdown of KAAE, Vladyslav Galimskiy's life did not become less intense. In 1900, he opened his art school and took part in dozens of exhibitions. Later, in 1916, he became a member of the organizers of Kyiv Society of Artists. Moreover, he was actively involved in charity. In particular, he participated in the organization of "living paintings" (small amateur performances): in March 1895 - in favor of a free hospital founded by Countess Sofia Ignatieva (Kievlyanin, 1895: 1), and in February 1902 - to raise funds for a new Roman Catholic Church in Kyiv (TsDIAK, spr. 4: 8-9 zv.).

\section{Conclusion}

The premier source that allows forming an idea of the exhibition activities of V. Galimskiy is exhibition catalogs of the late $X X^{\text {th }}$ - first half of $X^{\text {th }}$ century. Unfortunately, they have not published every time that greatly complicates the research activities. They are very poorly preserved (one can find only a small part of such publications in libraries and archives of Ukraine). As a rule, pre-revolutionary catalogs specified the titles of artworks without additional information, i.e., without date, technique, size, say nothing of art reproductions. Therefore, the author attaches the appendix comprising a list of works by V. Galimskiy exhibited at Kyiv exhibitions of the 1890 s and available in catalogs.

\section{Appendix}

\section{8}

Catalog of paintings and ancient art objects, weapons, and archeological antiquities of the museum in Kiev on Khreshchatyk, near Bessarabka, № 56, 1888. A compiler: the head of the museum I. Hoynovskiy. Kiev: Type. E. T. Kerer, held by N. Pilyuschenko and S. Brodovskim, 1888.

1. № 51. Ukrainian steppe.

2. № 52. Birch Alley behind the Korsun Garden.

3. № 53. Rocks in the Korsun Garden.

4. № 54. Mill at dawn from the outskirts of Korsun.

\section{0}

Catalogue of art exhibition in the Exchange Hall. K: D. S. Povalsky Printing House, 8 Mikhailovskaya Street, 1890. [Permitted by censorship on January 9, 1890.]

1. № 3. A hot day.

2. № 6. Around midnight.

3. № 11. An oak forest.

4. № 20. In a thunderstorm.

5. № 22. Moonrise.

6. № 27. Spring small rain

7. № 31. A deserted park.

8. № 32. A moonlit night.

9. № 38. The portrait of Mrs. S.

10. № 39. An autumn morning.

11. № 63. Dnieper horizons.

12. № 66. A rural corner.

13. № 67. Twilight. 


\section{1}

Catalog of art exhibition at the Exchange Hall. K.: K. N. Milevskyi Printing House, 10 Proreznaya Street, 1891. [Permitted by censorship on January 24, 1891]

1. № 10. A foggy morning.

2. № 11. A spring downpour.

3. № 12. Desert caravan.

4. № 13. At a moonlit night.

\section{2}

Kiev Association for Arts Promotion. Catalog of the exhibition of studies and sketches. 1892, K.: K. N. Milevskyi Printing House, 21 Fundukleevskaya Street, 1892. [Permitted by censorship on September 26, 1892.]

1. № 16. A street in Constantinople.

2. № 17. Shepherds.

3. № 18. Morning.

4. № 19. Noon.

5. № 20. On the river.

6. № 21. The mill.

Catalog of art exhibition in the Exchange Hall. K.: K. N. Milevskyi Printing House, 21 Fundukleevskaya Street, 1892. [Permitted by censorship on December 24, 1892.]

1. № 8. Night came.

2. № 9. A dead mill.

3. № 10. Constantinople at a moonlight night.

4. № 11. The cloud came.

5. № 12. A summer day.

6. № 13. A grinder in Constantinople.

7. № 14. Study.

8. № 15. Study.

9. № 16 . Study.

\section{4}

Catalog of the I exhibition of Kiev Association of Art Exhibitions. K.: K. N. Milevskyi Printing House, 21 Fundukleevskaya Street, 1894. [Permitted by censorship on January 28, 1894.]

1. № 19. Late.

2. № 20. At the stream.

3. № 21. Night on the Dnieper.

4. № 22. In a mud season.

5. № 23. Niagara Falls.

6. № 24. An Arab.

Catalog of the II exhibition of Kiev Association of Art Exhibitions. K.: K. N. Milevskyi Printing House, 21 Fundukleevskaya Street, 1894. [Permitted by censorship on December 27, 1894.] 
1. № 5. Forest stream.

2. № 6. A vet's reception day.

3. № 7. The water seller of Tunisia.

4. № 8. In front of khata.

5. № 9. Bouquet.

1895

Catalog of the III exhibition of Kiev Association of Art Exhibitions. K.: K. N. Milevskyi Printing House, 21 Fundukleevskaya Street, 1895. [Permitted by censorship on December 29, 1895.]

1. № 14. New moon

2. № 15. North

3. № 16. Nocturno.

1896

Kiev Association for Arts Promotion. 9 Boulevard Street. Catalog of a temporary exhibition of Russian and foreign artists. Kiev, 1896. K.: Type. S. V. Kulzhenko, NovoElisavetskaya, 1896. [Permitted by censorship on November 2, 1896.]

\section{1. № 29. Night.}

Catalog of the IV exhibition of Kiev Association of Art Exhibitions. K.: K.N. Milevsky Printing House, B.-Vladimirskaya St., 21, 1897. [Permitted by censorship on December 28, 1896.]

1. № 17. Indian summer in the steppe.

2. № 18. September

3. № 19. Forest peaks.

4. № 20. July morning.

5. № 21 Fresh shoots.

6. № 22. In the garden.

7. № 23. 12 studies.

\section{7}

Catalog of the V exhibition of Kiev Association of Art Exhibitions. K.: K. N. Milevsky Printing House, B.-Vladimirskaya St., 21, 1897. [Permitted by censorship on December 23, 1897.]

1. № 10. An apiary.

2. № 11. Winter

3. № 12. At a moonlit night.

4. № 13. Overflow of the Dnieper.

5. № 14. In the meadow.

6. № 15. Dawn.

7. № 16. Studies. 


\section{0}

Catalog of the VI exhibition of Kiev Association of Art Exhibitions. K.: K.N. Milevsky Printing House, 31 B.-Vladimirskaya St., 1900. [Permitted by censorship on December 31, 1899.]

1. № 16. Among the flowers.

2. № 17 . After the rain.

3. № 18. Noon.

4. № 19. Forest river.

5. № 20. Idyll.

6. № 21. Spring

\section{References}

1. [B. p.]. (1900). Kiev. Hronika zhurnala «Iskusstvo i hudozhestvennaya promyshlennost». [Art and Art Industry Journal Chronicle]. 1899-1900, 10 (20 fevralya), 228. [in Russian]

2. [B. p.]. (1894). Pervaya vystavka Obshestva kievskih hudozhnikov. [First exhibition of the Society of Kiev Artists]. Kievlyanin, 33 (2 fevralya), 2. [in Russian]

3. [B. p.]. (1913). Yubilej V. M. Galimskogo. [Jubilee of V. M. Galimskiy]. Russkoe slovo, 94 (24 aprelya (7 maya)), 7. [in Russian]

4. [B. p.]. (1913). Yubilej hudozhnika. [Artist's anniversary]. Kievlyanin, 107 (19 aprelya),

4. [in Russian]

5. [Announcement of the opening of an exhibition of paintings by the Kiev Association of Art Exhibitions]. (1900). Kievlyanin, 1 (1 yanvarya), 1. [in Russian]

6. [Announcement of an exhibition of a painting "Messalina” by V. Kotarbinsky from February 5]. (1894). Kievlyanin, 40 (9 fevralya), 3. [in Russian]

7. [Announcement of an exhibition of a painting "Messalina” by V. Kotarbinsky from February 5]. (1894). Zhizn i iskusstvo, 65 (16 fevralya), 1. [in Russian] [Announcement of an exhibition of a painting “Messalina” by V. Kotarbinsky]. (1894). Kievskoe slovo, № 2185 (12 fevralya), 1; 2187 (14 fevralya), 1; 2189 (16 fevralya), 1. [in Russian]

8. [Announcement of live paintings by Academician V. Galimskiy]. (1895). Kievlyanin, 81 (22 marta), 1. [in Russian]

9. [P. N.]. (1893). Godichnaya vystavka kartin mestnyh hudozhnikov. [Annual Exhibition of the local artists]. Kievskoe slovo, 1803 (21 yanvarya). 2-3; 1804 (22 yanvarya), 2. [in Russian] 10. [Photographic portrait of $V$. Galimskiy on the occasion of his anniversary]. (1914). Kłosy Ukrainskie, 2 (30 marca), 9. [in Polish]

11. Official Catalogue of exhibits World's Columbian Exposition. (1893). URL: https://babel. hathitrust.org/cgi/pt?id=uc1. \$b36295\&view $=1$ up\&seq $=6$

12. W. [Gorlenko V.]. (1889). Vystavka kartin kievskih hudozhnikov. [Exhibition of paintings by Kiev artists]. Kievskaya starina, 4, 203-205. [in Russian]

13. Z. (1892). Vystavka kartin kievskih hudozhnikov. [Exhibition of paintings by Kiev artists]. Kievskaya starina, 2, 331-333. [in Russian]

14. Derzhavnyi arkhiv Kyivskoi oblasti (DAKO), f. 2 (Kantseliariia Kyivskoho tsyvilnoho hubernatora), op. 26, spr. 53; spr. 261.

15. Derzhavnyi arkhiv m. Kyieva (DAK), f. 95 (Kyivske pershe realne uchylyshche), op. 2, spr. 55.

16. Dilletant. (1894). Dve vystavki. [Two exhibitions] Kievlyanin, 50 (19 fevralya), 1-2.

17. Don Bazilio [Karickij A.]. (1900). Hudozhestvennaya vystavka. [Art Exhibition] Kievskoe slovo, 4310 (8 yanvarya), 3; 4313 (11 yanvarya), 2; 4315 (13 yanvarya), 2. [in Russian] 
18. Igolka. (1891). Mysli vsluh. Ovystavkah kartin v Kieve. [Thoughts Out Loud. About the Exhibitions of paintings in Kiev]. Kievskoe slovo, 1167 (7 fevralya), 2-3; 1169 (9 fevralya), 2. [in Russian] 19. Instytut rukopysu Natsionalnoi biblioteky Ukrainy im. V. I. Vernadskoho (IR NBUV), f. 195 (Arkhiv H. V. Shvartsa), od. zb. 2. [in Ukrainian]

20. Kartiny hudozhnika V. M. Galimskogo (K 25-ti letnemu yubileyu). (1913). [Paintings of the artist V. M. Galimskiy (on the 25th anniversary)]. Kievskaya mysl. Prilozhenie $k$ № 121, 19 (3 maya), 148-149. [in Russian]

21. Kovalenko, O. (1972). Z istorii khudozhnikh ob'iednan Ukrainy. [From the history of art associations in Ukraine] Ukrainskyi istorychnyi zhurnal, 1, 83. [in Ukrainian]

22. Kondakov, S. N. (2002). Spisok russkih hudozhnikov k Yubilejnomu spravochniku Imperatorskoj Akademii hudozhestv. [List of Russian Artists for the Imperial Academy of Arts Jubilee Handbook] Moskva: Izd-vo ZAO «Antik-Biznes-Centr». [in Russian]

23. Kuzmin, E. M. (1900). Iz Kieva. [From Kiev]. Iskusstvo i hudozhestvennaya promyshlennost, 18 (mart), 317. [in Russian]

24. Naukovi arkhivni fondy rukopysiv i fonozapysiv Instytutu mystetstvoznavstva, folklorystyky ta etnolohii imeni M. T. Rylskoho Natsionalnoi Akademii Nauk Ukrainy (NAFRF IMFE), f. 20-3 (Fond Tovarystva pivdennorosiiskykh khudozhnykiv), spr. 93, 95.

25. Severyuhin, D. Ya., Lejkind, O. L. (1992). Zolotoj vek hudozhestvennyh obedinenij v Rossii $i$ SSSR (1820-1932): Spravochnik. [The Golden Age of Art Associations in Russia and the USSR (1820-1932): Handbook]. SPb: Izd-vo Chernysheva. [in Russian]

26. Skitalec. (1896). 3-ya vystavka kartin kievskogo tovarishestva. [The 3rd exhibition of paintings of the Kiev Association]. Kievlyanin, 11 (11 yanvarya), 2-3.[in Russian]

27. Tovarishestvo peredvizhnyh hudozhestvennyh vystavok, 1869-1899: Pisma, dokumenty: [V 2 kn.]. [Association of Travelling Art Exhibitions](1987). M.: Iskusstvo, T. II. [in Russian]

28. Ustav Kievskogo tovarishestva hudozhestvennyh vystavok. (1893). [Charter of the Kiev Association of Art Exhibitions] K.: Tipografiya K. N. Milevskogo. [in Russian]

29. Fedoruk, O. (2009). Yevhen Vzheshch - neordynarnyi variant kyivskoho pleneryzmu. [Eugen Vrzeszcz - an unconventional version of Kyiv's plenarism] Khudozhnia kultura. Aktualni problemy: nauk. visnyk, 6, 334-376. [in Ukrainian]

30. Fedoruk, O. (2009). Peizazhnyi zhyvopys Yevhena Vzheshcha. [Landscape paintings by Eugen Vrzeszcz]. Khronika 2000. Ukraina - Polshcha: dialoh uprodovzh tysiacholit. Zb. nauk. prats. K.: Feniks, 80, 509-561. [in Ukrainian]

31. Tsentralnyi derzhavnyi istorychnyi arkhiv Ukrainy, m. Kyiv (TsDIAK Ukrainy), f. 442 (Kantseliariia Kyivskoho, Podilskoho ta Volynskoho heneral-hubernatora), op. 544, spr. 262; op. 622, spr. 233; op. 623, spr. 43, spr. 183; op. 624, spr. 51; op. 625, spr. 58; op. 626, spr. 60; op. 852, spr. 4 [in Ukrainian]

32. Ertel, A. (1893). I-ya vesennyaya vystavka kartin. [The first spring exhibition of paintings]. Kievskoe slovo, 1875 (5 aprelya), 1. [in Russian]

33. Ertel, A. (1894). I-ya vystavka kartin kievskogo tovarishestva hudozhestvennyh vystavok. [The first Exhibition of Paintings of the Kiev Association of Art Exhibitions] Kievskoe slovo, 2177 (4 fevralya), 2. [in Russian]

34. Ertel, A. (1893). Godichnaya vystavka kartin mestnyh hudozhnikov. [Annual Exhibition of paintings by local artists]. Kievskoe slovo, 1796 (14 yanvarya), 2-3. [in Russian]

35. Ertel, A. (1891). Godichnaya vystavka kievskih hudozhnikov. [Annual Exhibition of paintings by Kiev artists]. Kievlyanin, 285 (31 dekabrya), 2. [in Russian]

36. Ertel, A. (1891). Mestnaya vystavka kartin. [Local Art Exhibition]. Kievlyanin, 25 (30 yanvarya), 3. [in Russian] 